Rev. Fac. Agron. (LUZ). 2021, 38: 176-198. Enero-Marzo.

DOI: https://doi.org/10.47280/RevFacAgron(LUZ).v38.n1.09

ISSN 2477-9407

\title{
Tipificación socio-agronómica y energética de productores de maíz en la región Frailesca, Chiapas, México
}

\section{Socio-agronomic and energy typification of maize-farmers in the Frailesca region of Chiapas, Mexico}

\section{Tipificação socioeconômica e energética de produtores de milho na região de Frailesca, Chiapas, México}

Franklin B. Martínez-Aguilar ${ }^{1}$, Francisco GuevaraHernández ${ }^{2^{*}}$, Manuel A. La O-Arias ${ }^{2}$, Carlos E. AguilarJiménez ${ }^{2}$, Luis A. Rodríguez-Larramendi ${ }^{3}$ y René Pinto-Ruiz ${ }^{2}$

\begin{abstract}
${ }^{1}$ Estudiante de Doctorado en Ciencias Agropecuarias y Sustentabilidad. Universidad Autónoma de Chiapas (UNACH). Carretera OcozocoautlaVillaflores km. 84.5 C.P. 30470. Villaflores, Chiapas. Correo electrónico: franklin.martinez@unach.mx, (i); ${ }^{2}$ Profesor de la Universidad Autónoma de Chiapas (UNACH), Facultad de Ciencias Agronómicas. Carretera Ocozocoautla-Villaflores km. 84.5 C.P. 30470 Apdo. Postal 78, Villaflores, Chiapas. Correo electrónico: (FGH): fragueher@prodigy.net.mx, (D; (MALO) manuel.arias@unach.mx, (D); (CEAJ) ejimenez@unach.mx, (i); (RPR) rene. pinto@unach.mx, (D); ${ }^{3}$ Profesor de la Facultad de Ingeniería, Sede Villa Corzo. Universidad de Ciencias y Artes de Chiapas (UNICACH). Carretera Villa Corzo-Monterrey km 3, Villa Corzo CP 30520, Villa Corzo, Chiapas, México. Correo electrónico: alfredo.rodriguez@unicach.mx, (D.
\end{abstract}

\section{Resumen}

La identificación y caracterización de tipos de productores del agroecosistema maíz es imprescindible para el desarrollo de estrategias socio-productivas efectivas y sustentables. En cuatro municipios de la región Frailesca del estado de Chiapas, México; se tipificó a los productores de maíz y se caracterizó su agroecosistema desde el punto de vista de criterios de socioeconómicos, productivos y energéticos. Además, se determinó su relación con las formas de manejo del agroecosistema convencional, agroecológica y mixta. Fue una investigación socio-agronómica del

Recibido el 25-05-2020 • Aceptado el 31-07-2020.

*Autor de correspondencia. Correo electrónico: francisco.guevara@unach.mx 
tipo descriptiva y con un enfoque de sistemas y flujos energéticos. La muestra empleada fue de 300 productores de maíz. Para el manejo de los datos, se empleó la estadística descriptiva y análisis multivariado exploratorio de componentes principales y conglomerados para construir tipologías. Se identificaron cinco tipos de productores de maíz sobre la base de seis componentes que explicaron $83 \%$ de la varianza total. Dentro de estas componentes se destacaron: "Rendimiento y Eficiencia", "Perfil Maíz" (se refiere al peso del componente maíz dentro del sistema productivo) y "Consumo Energético". Los grupos de productores identificados se etiquetaron como: "Productores pequeños", "Productores mayores", "Productores mixtos ganadería-maíz", "Productores de subsistencia" y "Productores maízrastrojo". Todos los grupos identificados se caracterizan por tener superficies pequeñas para la siembra de maíz, pero se consideran con una eficiencia energética aceptable, superior a $10 \mathrm{MJ}$ y rendimientos entre 2,8 y 4,0 t.ha-1, superiores a la media para el estado de Chiapas. En la región Frailesca predomina el manejo de agricultura convencional, en el $86 \%$ de los sistemas estudiados.

Palabras clave: caracterización, Zea mays L., tipos de productores.

\section{Abstract}

The identification and characterization of farmers types in the maize agroecosystem is an essential element for the development of effective and sustainable socio-productive strategies. In four municipalities of the Frailesca region in Chiapas, Mexico; maize farmers were typified and their agroecosystem was characterized regarding the criteria: socioeconomic, productive and energy efficiency. Besides, farmers relation to conventional, agro-ecological and mixed production strategies was determined. It was an exploratory socio-agronomic and descriptive research focused on a system approach and energy flows. The sample used was 300 farmers. For data management, descriptive statistics and exploratory multivariate analysis of principal components and clusters were used to construct the typologies. Five types of farmers-groups were identified based on six components that explained $83 \%$ of the total variance. Among these components, the following stood out: "Yield and Efficiency", "Maize profile" (refers to the type of maize and its importance within the system) and "Energy Consumption". The typified groups of farmers were labeled as: "Small farmers", "Major farmers", "Mixed livestockmaize farmers", "Subsistence farmers" and "Maize-stubble producers". All groups are characterized by having small maize areas, but they are considered to have an acceptable energy efficiency, greater than $10 \mathrm{MJ}$ and yields between 2.8 and 4.0 t.ha ${ }^{-1}$, higher than the average for the state of Chiapas. All groups were efficient in the use of energy, as result of the high productive and economic capacity of the agroecosystem. The maize yield is between 2.8 and 4.0 t.ha $^{-1}$ and the energy efficiency is higher than $10 \mathrm{MJ}$. Conventional agriculture management predominates in the region in $86 \%$ of the studied systems.

Key words: characterization, Zea mays L., type of farmers. 
Rev. Fac. Agron. (LUZ). 2021, 38: 176-198. Enero-Marzo.

Martínez-Aguilar et al.

\section{Resumo}

A identificação e caracterização dos tipos de produtores do agroecossistema do milho são essenciais para o desenvolvimento de estratégias socioprodutivas eficazes e sustentáveis. Em quatro municípios da região Frailesca do estado de Chiapas, México; os produtores de milho foram tipificados e seu agroecossistema foi caracterizado do ponto de vista de critérios socioeconômicos, produtivos e energéticos. Além disso, foi determinada sua relação com as formas convencionais, agroecológicas e mistas de manejo do agroecossistema. Tratou-se de uma pesquisa sócio-agronômica descritiva com foco em sistemas e fluxos energéticos. A amostra utilizada foi de 300 produtores de milho. Para o gerenciamento dos dados, foram utilizadas estatísticas descritivas e análises exploratórias multivariadas de componentes principais e conglomerados para construir as tipologias. Cinco tipos de produtores de milho foram identificados com base em seis componentes que explicaram $83 \%$ da variância total. Dentre esses componentes, destacam-se: "Rendimento e Eficiência", "Perfil do Milho" (refere-se ao peso do componente milho no sistema de produção) e "Consumo de Energia". Os grupos de produtores identificados foram rotulados como: "Pequenos produtores", "Grandes produtores", "Produtores mistos de milho-pecuária", "Produtores de subsistência" e "Produtores de restolho de milho". Todos os grupos identificados se caracterizam por possuírem pequenas áreas para semeadura de milho, mas são considerados com eficiência energética aceitável, superior a $10 \mathrm{MJ}$ e produtividades entre 2,8 e 4,0 t.ha ${ }^{-1}$, superiores à média do estado. De chiapas. Na região de Frailesca, o manejo da agricultura convencional predomina em $86 \%$ dos sistemas estudados. Palavras-chave: caracterização, Zea mays L., tipos de produtores.

\section{Introducción}

En México, el cultivo de maíz es una de las actividades agrícolas más importantes. La superficie cultivada es de 3,8 millones de hectáreas y la producción promedio anual de 24,3 millones de toneladas (SIAP, 2018). En el estado de Chiapas, el $70 \%$ de la producción de maíz se envía a otros estados del país que no son autosuficientes (SAGARPA, 2017). Entre los municipios más productivos en el estado se encuentran Villaflores, Villa Corzo, El Parral y La Concordia, donde el cultivo ocupa alrededor del 17

\section{Introduction}

In Mexico, growing corn is one of the most important agricultural activities. The cultivated area is 3.8 million hectares and the average annual production of 24.3 million tons (SIAP, 2018). In the state of Chiapas, $70 \%$ of the corn production is sent to other states of the country that are not selfsufficient (SAGARPA, 2017). Among the most productive municipalities in the state are Villaflores, Villa Corzo, El Parral and La Concordia, where the crop occupies around $17 \%$ of the agricultural area and contributes $22 \%$ 
Rev. Fac. Agron. (LUZ). 2021, 38: 176-198. Enero-Marzo.

Martínez-Aguilar et al.

$\%$ de la superficie agrícola y aporta el $22 \%$ de la producción estatal (INEGI, 2018). El desarrollo productivo en estos municipios se sustenta en el empleo de variedades mejoradas y tecnologías convencionales. En este sentido, el $88 \%$ de los productores utilizan fertilizantes, $76 \%$ usa insecticidas y $65 \%$ herbicidas (Guevara et al., 2018). Además, el $32 \%$ de los productores usa semillas mejoradas, mientras que el $68 \%$ emplea semillas de origen local, conocidas como criollas (Delgado-Ruiz et al., 2018). Esto hace evidente una matriz de consumo energético básicamente industrial que conduce a emisiones de gases de efecto invernadero (IDAE, 2009; Ocaña, 2015).

En estos cuatro municipios, el rendimiento promedio de maíz, bajo temporal (lluvia estacional), es de 3,24 t.ha ${ }^{-1}$, superior a la media estatal de 1,9 t.ha ${ }^{-1}$ (SIAP, 2018). Estos resultados productivos se obtienen en una alta diversidad de combinaciones tecnológicas. La lógica productivista apoya la idea de que el empleo de insumos industriales incrementa la matriz de consumo energético, pero se compensa con la respuesta productiva. Sin embargo, otros puntos de vista asumen la idea de sustituir insumos industriales para reducir el consumo energético y obtener resultados productivos similares de una manera sustentable en el tiempo.

Ante esto, la sustentabilidad se concibe como la acción del hombre en relación a su ambiente y busca un equilibrio entre lo ecológico, lo económico y lo social para lograr mantener la producción de un sistema of the state production (INEGI, 2018). Productive development in these municipalities is based on the use of improved varieties and conventional technologies. In this sense, $88 \%$ of producers use fertilizers, $76 \%$ use insecticides and $65 \%$ herbicides (Guevara et al., 2018). In addition, 32 $\%$ of producers use improved seeds, while $68 \%$ use seeds of local origin, known as criollas (Delgado-Ruiz et al., 2018). This makes evident a basically industrial energy consumption matrix that leads to greenhouse gas emissions (IDAE, 2009; Ocaña, 2015).

In these four municipalities, the average maize yield, under temporary (seasonal rain), is 3.24 t.ha $^{-1}$, higher than the state average of 1.9 t.ha $^{-1}$ (SIAP, 2018). These productive results are obtained in a high diversity of technological combinations. The Productivist logic supports the idea that the use of industrial inputs increases the energy consumption matrix, but is offset by the productive response. However, other points of view assume the idea of substituting industrial inputs to reduce energy consumption and obtain similar productive results in a sustainable way over time.

In view of this, sustainability is conceived as the action of man in relation to his environment and seeks a balance between the ecological, the economic and the social in order to maintain the production of a system constantly over time and reduces the negative impact on the area resources (Toledo, 2015). In this sense, the corn agroecosystem for the area of study represents the largest economic 
de manera constante en el tiempo y disminuye el impacto negativo sobre los recursos de la zona (Toledo, 2015). En ese sentido, el agroecosistema maíz para la zona de estudio representa la mayor actividad económica y se desarrolla con una alta diversidad de racionalidades tecnológicas y socioeconómicas.

En esencia esta diversidad se distribuye de forma gradual, desde una racionalidad que promueve los ciclos agroecológicos de regeneraciónregulación (Altieri, 2002) hasta una racionalidad centrada en el productivismo que fomenta un proceso lineal $\mathrm{y}$ extractivo. En este espectro no solo se enmarcan las tecnologías productivas, sino también las estrategias de relación con el agroecosistema, la familia y el entorno socioeconómico. Un enfoque sistémico y el análisis energético, metodológicamente contribuyen a operacionalizar las variables implicadas y muchos de sus indicadores se proyectan como indicadores de sustentabilidad. Por ejemplo, los procesos de reciclaje de nutrientes se reflejan en el balance de insumos industriales requeridos y los procesos lineales en la relación entre energía consumida versus energía producida.

Por ello, la tipificación socioproductiva de los agricultores y la caracterización de su agroecosistema, bajo un enfoque sistémico y de eficiencia energética es muy importante en los análisis de sustentabilidad (Hellin et al., 2013; Purroy et al., 2016). En ese tenor, la identificación y caracterización de tipos de productores del agroecosistema maíz activity and is developed with a high diversity of technological and socioeconomic rationalities.

Inessence, this diversityisgradually distributed, from a rationality that promotes agroecological cycles of regeneration-regulation

(Altieri, 2002) to a rationality focused on productivism that fosters a linear and extractive process. In this spectrum, not only productive technologies are framed, but also strategies related to the agroecosystem, the family and the socioeconomic environment. A systemic approach and energy analysis methodologically contribute to operationalize the variables involved and many of its indicators are projected as sustainability indicators. For example, nutrient recycling processes are reflected in the balance of required industrial inputs and linear processes in the relationship between energy consumed versus energy produced.

For this reason, the socioproductive classification of farmers and the characterization of their agroecosystem, under a systemic and energy efficiency approach, is very important in sustainability analyzes (Hellin et al., 2013; Purroy et al., 2016). In this sense, the identification and characterization of types of producers of the corn agroecosystem is essential for the development of effective and sustainable socio-productive strategies. This segmentation allows development actors to work with recommendation and analysis domains, which are adjusted to the particularities of each agroecosystem and its forms of management (Méndez- 
Rev. Fac. Agron. (LUZ). 2021, 38: 176-198. Enero-Marzo.

Martínez-Aguilar et al.

es imprescindible para el desarrollo de estrategias socio-productivas efectivas y sustentables. Esta segmentación permite a los actores del desarrollo trabajar con dominios de recomendación y análisis, que se ajusten, a las particularidades de cada agroecosistema y sus formas de manejo (Méndez-Cortés et al., 2019). Por lo anterior, la presente investigación tuvo como objetivo tipificar a los productores de maíz y caracterizar su agroecosistema desde el punto de vista de la sustentabilidad con criterios socioeconómicos, productivos y energéticos, en cuatro municipios de la región Frailesca, de Chiapas.

\section{Materiales y métodos}

\section{Localización y características del área de estudio}

La investigación se llevó a cabo en cuatro municipios (Villaflores, Villa Corzo, El Parral y La Concordia) de la región Frailesca en el estado de Chiapas, México, ubicados entre las coordenadas $16^{\circ} 14^{\prime} 00^{\prime \prime} \mathrm{N} 93^{\circ} 16^{\prime} 09^{\prime \prime} \mathrm{O}$, y $16^{\circ} 14^{\prime} 00^{\prime \prime} \mathrm{N} 93^{\circ} 16^{\prime} 09^{\prime \prime} \mathrm{O}$ (Figura 1 ). Esta área geográfica, es la de mayor producción de maíz en el estado, con un rendimiento promedio de 3,24 t.ha ${ }^{-1}$ (INEGI, 2018), presenta una temperatura promedio $24,5{ }^{\circ} \mathrm{C}$, con $1200 \mathrm{~mm}$ de lluvia en el verano. Como contraparte, en la Frailesca predomina la agricultura de pequeña escala, donde los productores practican formas diferentes de manejo (convencional, agroecológica y mixta) del agroecosistema maíz, de acuerdo con las condiciones edafoclimáticas, los costos de
Cortés et al. 2019). Therefore, the present research aimed to typify corn producers and characterize their agroecosystem from the point of view of sustainability with socioeconomic, productive and energy criteria, in four municipalities of the Frailesca region of Chiapas.

\section{Materials and methods}

\section{Location and characteristics of the study area}

The investigation was carried out in four municipalities (Villaflores, Villa Corzo, El Parral and La Concordia) of the Frailesca region in the state of Chiapas, Mexico, located between coordinates $16{ }^{\circ} 14^{\prime} 00$ " N $93^{\circ} 16^{\prime} 09$ " W, and $16^{\circ} 14^{\prime} 00 "$ N $933^{\circ} 16^{\prime} 09 " \mathrm{~W}$ (Figure 1). This geographical area is the one with the highest corn production in the state, with an average yield of 3.24 t ha ${ }^{-1}$ (INEGI, 2018), it presents an average temperature of $24.5^{\circ} \mathrm{C}$, with $1200 \mathrm{~mm}$ of rain in the summer. As a counterpart, small-scale agriculture predominates in La Frailesca, where producers practice different forms of management (conventional, agroecological and mixed) of the maize agroecosystem, according to the edaphoclimatic conditions, production costs, the destination of the product and the changes of the region cultivation patterns (Ocaña, 2015; Guevara et al., 2018).

\section{Methodology}

For the typification of producers, an interdisciplinary methodology was used with a development systemic approach (Chambers, 1993; 
Rev. Fac. Agron. (LUZ). 2021, 38: 176-198. Enero-Marzo.

Martínez-Aguilar et al.

ISSN 2477-9407

producción, el destino del producto y los cambios en los patrones de cultivo en la región (Ocaña, 2015; Guevara et al., 2018).
Hagmann, 1999). Socioeconomic, productive and environmental criteria were used as suggested by GuevaraHernández (2007) and Rodríguez

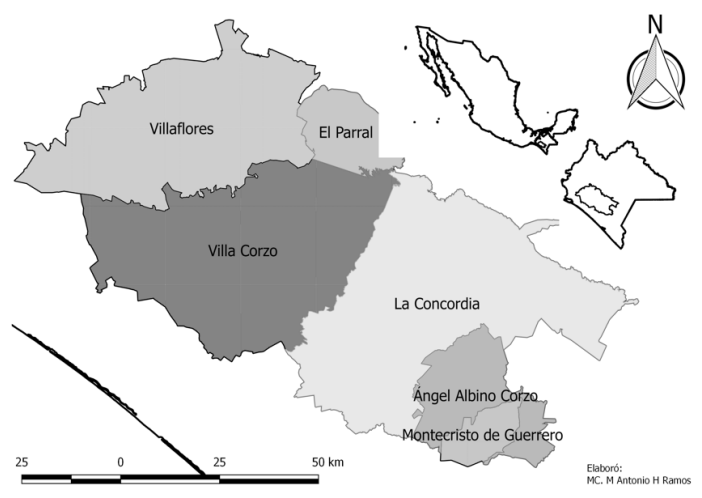

Figura 1. Localización de los municipios productores de maíz en la Frailesca, Chiapas (México).

Figure 1. Location of corn producing municipalities in La Frailesca, Chiapas (Mexico).

\section{Metodología}

Para la tipificación de productores se utilizó una metodología interdisciplinaria con un enfoque sistémico para el desarrollo (Chambers, 1993; Hagmann, 1999). Se utilizaron criterios socioeconómicos, productivos y ambientales de acuerdo a lo sugerido por GuevaraHernández (2007) y Rodríguez y Guevara (2009). Para ello, se tomó como base la población reportada por SAGARPA de 7.888 productores de maíz, con 54.873 ha cultivadas bajo siembra de temporal (SIAP, 2018). El tipo de muestreo utilizado fue aleatorio simple y para definir el tamaño de muestra se empleó la fórmula de Scheaffer y Mendenhall and Guevara (2009). To do so, the population reported by SAGARPA of 7,888 corn producers was taken as a basis, with 54,873 ha cultivated under rainfed sowing (SIAP, 2018). The type of sampling used was simple randomized and the Scheaffer and Mendenhall (2004) formula was used to define the sample size. A total of 300 producers from 75 communities were studied. Producer interviews and surveys were applied to analyze 17 variables grouped into socioeconomic, productive and energy criteria of the corn agroecosystem (Table 1). To estimate the energy indicators, the total energy inputs and outputs in the production process were calculated, from the product the total volume of 
Rev. Fac. Agron. (LUZ). 2021, 38: 176-198. Enero-Marzo.

Martínez-Aguilar et al.

(2004). Se estudiaron un total de 300 productores de 75 comunidades. Se aplicaron entrevistas y encuestas a los productores para analizar 17 variables agrupadas en criterios socioeconómicos, productivos y energéticos del agroecosistema maíz (Cuadro 1). Para la estimación de los indicadores energéticos se calculó el total de entradas y salidas energéticas en el proceso productivo, a partir del producto el volumen total de cada elemento por su equivalencia energética representada en el Cuadro 2, de acuerdo con Funes (2009). La eficiencia energética es la razón: producción de energía/consumo, mientras que la intensidad energética es la razón volumen de producción / consumo energético. En este sentido se consideró la energía directa para el cálculo de las entradas y salidas del sistema (Pimentel, 1980). each element by its energy equivalence represented in Table 2, according to Funes (2009). Energy efficiency is the ratio: energy production / consumption, while energy intensity is the ratio volume of energy production / consumption. In this sense, direct energy was considered to calculate the inputs and outputs of the system (Pimentel, 1980).

\section{Information analysis}

To reduce the dimensionality of the study variables, a principal component analysis was applied (Escobar and Berdegué, 1990) where the components with eigenvalues greater than one were extracted. The extracted components were considered as new variables and were used in the cluster analysis to establish groups of producers, based on the forms of management of the agroecosystem with similar characteristics. To establish

\section{Cuadro 1. Criterios y variables estudiadas para tipificar productores y caracterizar el agroecosistema maíz en la región Frailesca de Chiapas.}

Table 1. Criteria and variables studied to typify producers and characterize the maize agroecosystem in the Frailesca region of Chiapas.

Criterios

Ingresos totales (pesos mexicanos)
Comercialización maíz elote
Comercialización maíz rastrojo

Socioeconómicos

Ingresos por la venta (maíz) (pesos mexicanos)

Ingresos por la venta (rastrojo) (pesos mexicanos)

Costos de producción (pesos mexicanos) 25: 1 USD
Superficie agrícola (ha)

Superficie forestal (ha)

Superficie maíz (ha)

Productivos

Superficie ganadera (ha)

Producción de rastrojo (t.ha $\left.{ }^{-1}\right)$

Rendimiento de maíz (t.ha-1)

Intensidad energética $(\mathrm{kg} / \mathrm{MJ})$

Energía producida $\left(\mathrm{MJ} / \mathrm{ha}^{-1}\right)$

Rendimiento energético $\left(\mathrm{kg} / \mathrm{MJ}^{-1}\right)$

Energéticos 
Rev. Fac. Agron. (LUZ). 2021, 38: 176-198. Enero-Marzo.

Martínez-Aguilar et al.

ISSN 2477-9407

Cuadro 2. Equivalencia energética de los insumos directos empleados y productos utilizados en el análisis.

\begin{tabular}{|c|c|c|c|}
\hline Insumo & Unidad & Kcal/unidad & Fuente \\
\hline Trabajo humano & Horas & 250 & (Funes, 2001) \\
\hline Trabajo animal & Horas & 1800 & (Funes, 2001) \\
\hline Semilla (en general) & $\mathrm{kg}$ & 25714,3 & (Perales et al., 2005) \\
\hline Diésel & $\mathrm{L}$ & 9243 & (Masera y Astier, 1995) \\
\hline Gasolina & $\mathrm{L}$ & 8150 & (Masera y Astier, 1995) \\
\hline Sulfato de amonio (21\%) & $\mathrm{kg}$ & 10755 & (IDAE, 2009) \\
\hline Herbicida & $\mathrm{L}$ & 57000 & (Funes, 2001) \\
\hline Insecticida & $\mathrm{L}$ & 44000 & (Funes, 2001) \\
\hline Maquinaria & & 21000 & (Masera y Astier, 1995) \\
\hline Tractor agrícola & Horas & 1015,4 & (Funes et al., 2011) \\
\hline Producto (Maíz, grano seco) & $\mathrm{kg}$ & 3656,7 & (Funes, 2009) \\
\hline Frijol & $\mathrm{kg}$ & 3322,1 & (Funes, 2009) \\
\hline
\end{tabular}

\section{Análisis de información}

Para reducir la dimensionalidad de las variables de estudio, se aplicó un análisis de componentes principales (Escobar y Berdegué, 1990) en el que se extrajeron los componentes con autovalores superiores a uno. Los componentes extraídos se consideraron como nuevas variables y se emplearon en el análisis de conglomerados para establecer grupos de productores, a partir de las formas de manejo del agroecosistema con características similares. Para establecer asociaciones entre los tipos definidos de productores y las formas de manejo de agroecosistema se realizaron análisis factoriales de correspondencias múltiples. Finalmente, se aplicaron análisis de varianza simples- y la prueba de Duncan para identificar las variables originales que aportaron significativamente a la diferenciación de los tipos de productores. Se utilizó el software Statistica (StatSoft, 2007). associations between the defined types of producers and the forms of agroecosystem management, factorial analyzes of multiple correspondences were carried out. Finally, simple analysis of variance and Duncan's test were applied to identify the original variables that significantly contributed to the differentiation of the types of producers. The Statistica software (StatSoft, 2007) was used.

\section{Results and discussion}

The principal components analysis (AFCP) allowed the identification of six components or factors that explained $83 \%$ of the total variance. Of the 17 variables included, the following stand out in the conformation of the components and the establishment of typologies: yield and efficiency energy consumption, corn profile, corn and stubble marketing, corn trade and nonagricultural surface.

The most important differences between the forms of agroecosystem 
Rev. Fac. Agron. (LUZ). 2021, 38: 176-198. Enero-Marzo.

Martínez-Aguilar et al.

ISSN 2477-9407

\section{Resultados y discusión}

El análisis de componentes principales (AFCP) permitió identificar seis componentes o factores que explicaron el $83 \%$ de la varianza total. De las 17 variables incluidas, destacaron en la conformación de las componentes y el establecimiento de tipologías, el rendimiento y eficiencia, consumo energético, perfil maíz, comercialización de elote y rastrojo, comercio de elote y superficie no agrícola (Cuadro 3) management studied are reflected in terms of their efficiency and their profile for cultivation. These two components explain practically half of the variability between forms of management and combine a total of nine original variables. It is relevant to mention that energy efficiency is associated to production yields, within Component I: "Performance and Efficiency", but not correlated with Component III: "Energy consumption". This means that the use of industrial inputs does not always

\section{Cuadro 3. Componentes principales y porcentaje de la varianza extraída y la acumulada.}

\section{Table 3. Main components and percentage of the extracted and accumulated variance.}

\begin{tabular}{|c|c|c|c|}
\hline Componente & Variable original & Correlación & $\begin{array}{c}\text { Varianza explicada } \\
\text { acumulada }\end{array}$ \\
\hline \multirow{5}{*}{$\begin{array}{l}\text { Rendimiento y } \\
\text { eficiencia }\end{array}$} & Rendimiento (kg/ha) & 0,96 & \multirow{5}{*}{$26 \%$} \\
\hline & Energía producida (Mcal) & 0,96 & \\
\hline & Rendimiento energético & 0,88 & \\
\hline & Eficiencia energética & 0,88 & \\
\hline & Personas alimentadas energía & 0,96 & \\
\hline \multirow{4}{*}{ Perfil Maíz } & Superficie agrícola & 0,88 & \multirow{4}{*}{$46 \%$} \\
\hline & Superficie maíz & 0,92 & \\
\hline & Ingresos Maíz grano & 0,91 & \\
\hline & Ingresos totales & 0,91 & \\
\hline \multirow{2}{*}{$\begin{array}{l}\text { Consumo } \\
\text { energético }\end{array}$} & Energía directa & 0,98 & \multirow{2}{*}{$57 \%$} \\
\hline & Intensidad energética & 0,90 & \\
\hline \multirow{2}{*}{$\begin{array}{l}\text { Comercialización } \\
\text { de elote y rastrojo }\end{array}$} & Comercialización (Maíz en elote) & $-0,82$ & \multirow[b]{2}{*}{$65 \%$} \\
\hline & Comercialización (Maíz Rastrojo) & $-0,83$ & \\
\hline \multirow[b]{2}{*}{ Comercio de elote } & Ingresos Elote & 0,87 & \multirow[b]{2}{*}{$74 \%$} \\
\hline & Costo total producción de maíz & 0,85 & \\
\hline \multirow{2}{*}{$\begin{array}{l}\text { Superficie no } \\
\text { agrícola }\end{array}$} & Superficie ganadera (ha) & $-0,84$ & \multirow[b]{2}{*}{$83 \%$} \\
\hline & Superficie forestal (ha) & $-0,77$ & \\
\hline
\end{tabular}


Rev. Fac. Agron. (LUZ). 2021, 38: 176-198. Enero-Marzo.

Martínez-Aguilar et al.

ISSN 2477-9407

Las diferencias más importantes entre las formas de manejo del agroecosistema estudiadas se reflejan en cuanto a su eficiencia y su perfil para el cultivo. Estos dos componentes explican prácticamente la mitad de la variabilidad entre formas de manejo y combinan un total de nueve variables originales. Es relevante mencionar que la eficiencia energética está asociada a los rendimientos productivos, dentro de la Componente I: "Rendimiento y Eficiencia", pero no correlacionada con la Componente III: "Consumo energético". Esto significa que el empleo de insumos industriales no siempre tiene un efecto productivo suficiente y que bajo formas de manejo del agroecosistema de menor consumo de estos, también se logran obtener rendimientos competitivos.

\section{Tipificación de productores}

Se conformaron cinco grupos o tipos de productores a partir de las puntuaciones resultantes del análisis factorial de componentes principales, usando el método de la distancia euclidiana (Figura 2). have a sufficient productive effect and that under forms of agroecosystem management with lower consumption of these, competitive yields are also achieved.

\section{Producer classification}

Five groups or types of producers were formed from the scores resulting from the factorial analysis of principal components, using the method of Euclidean distance (Figure 2).

Type I ("Small corn growers") includes $27 \%$ of producers. They are characterized by obtaining the highest yields and energy-productive efficiency; In addition, this type has a high profile for its products marketing. However, they cultivate in small areas (1.25 ha on average) with low energy consumption. These producers are capable of producing more energy in the form of agricultural products than they consume in cultural activities within the agroecosystem (Delgado, 2017). From the economic point of view, the high marketing profile

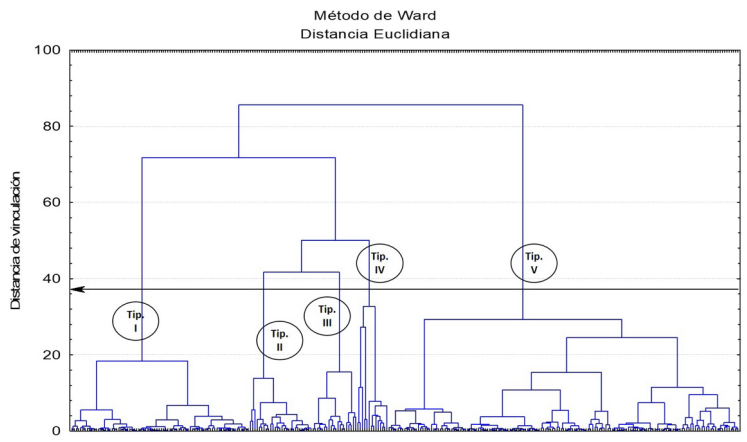

Figura 2. Tipología de productores de maíz en cuatro municipios de la Frailesca, Chiapas; formados a partir de los clústeres del análisis de conglomerados jerárquicos.

Figure 2. Typology of maize producers in four municipalities of La Frailesca, Chiapas; formed from the clusters of hierarchical cluster analysis. 
Rev. Fac. Agron. (LUZ). 2021, 38: 176-198. Enero-Marzo.

Martínez-Aguilar et al.

El tipo I ("Maiceros pequeños") incluye el $27 \%$ de productores. Se caracterizan por obtener los más altos rendimientos y eficiencia energéticaproductiva; además, presenta un perfil alto de comercialización de sus productos. Sin embargo, cultivan en superficies pequeñas (1,25 ha promedio) con bajo consumo de energía. Estos productores son capaces de producir más energía en forma de productos agropecuarios que la que consumen en actividades culturales dentro del agroecosistema (Delgado, 2017). Desde el punto de vista económico, el perfil alto de comercialización se relacionó con la cercanía del área de producción con los espacios de acopio de los productos agrícolas (Delgado-Ruiz et al., 2018).

El tipo II ("Productores mayores" o Maiceros) representa al $9 \%$ de los productores. Son netamente productores de maíz y, en general, similares al tipo I, en cuanto a la eficiencia energética alta y su proyección hacia la comercialización. Pero se diferencian por tener superficies de cultivo mucho mayores (7,38 ha promedio).

El tipo III ("Productores de subsistencia" o de bajo perfil) está conformado por el $7 \%$ de los casos, y se caracteriza por practicar una agricultura de subsistencia y autoconsumo, se encuentran en las zonas marginales y con potencial productivo bajo. Esto se refleja en la eficiencia energética baja y la superficie pequeña de maíz cultivado. $\mathrm{Al}$ respecto, Sánchez et al. (2014) indican que los productores que practican una agricultura tradicional se encuentran en una posición geográfica marginada y más lejana a los puntos de venta del was related to the proximity of the production area to the storage spaces for agricultural products (DelgadoRuiz et al. 2018).

Type II ("Major Producers" or Maiceros), represents $9 \%$ of the producers. They are clearly corn producers and, in general, similar to type I, in terms of high energy efficiency and their projection towards commercialization. But they differ by having much larger cultivation areas (7.38 ha on average).

Type III ("subsistence producers" or low-profile) is made up of $7 \%$ of the cases, and is characterized by practicing subsistence agriculture and self-consumption, they are found in marginal areas and with low productive potential. This is reflected in the low energy efficiency and the small acreage of corn grown. In this regard, Sánchez et al. (2014) indicate that producers who practice traditional agriculture are in a marginalized geographical position and further away from the grain sales points, where intermediaries are used as a mechanism to sell the production that needs to be sold. This is due to the fact that the cultivation areas are mainly in the surrounding areas or buffer zones of protected natural reserves and the orography that is presented is of the mountains relief type.

Type IV ("Mixed livestock-corn producers") represents $5 \%$ of the producers, their profile is nonagricultural due to their livestock activity and in some cases forestry. It also presents a high projection in the economic components. Their forms of 
Rev. Fac. Agron. (LUZ). 2021, 38: 176-198. Enero-Marzo.

\section{Martínez-Aguilar et al.}

ISSN 2477-9407

grano, donde el intermediarismo es utilizado como mecanismo de venta de la producción que requiere ser vendida. Esto se debe a que las áreas de cultivo se encuentran principalmente en zonas aledañas o de amortiguamiento de reservas naturales protegidas y la orografía que se presenta es del tipo relieve montañoso.

El tipo IV ("Productores mixtos ganadería-maíz") representa el $5 \%$ de los productores, su perfil es no-agrícola por su actividad ganadera y en algunos casos forestal. Presenta además una proyección alta en las componentes económicas. Sus formas de producción de maíz son más dinámicas y tienen dos o más cosechas en el año, ya que cuentan con riego (Figura 3). corn production are more dynamic and have two or more harvests in the year, since they have irrigation (Figure 3).

Type V ("Corn-stubble producers" or low profile II), is the majority, constituted by $52 \%$ of the producers. This group is limited in the "Corn Profile" component and they complement their income strategy with the marketing of stubble. They show lower levels of efficiency than the rest of the groups due to the export of stubble from the agroecosystem and reduce the nutrient recycling processes associated with conservation agriculture. This is consistent with its poorly productive soils subject to degradation processes described by López et al. (2018) and López et al. (2019).

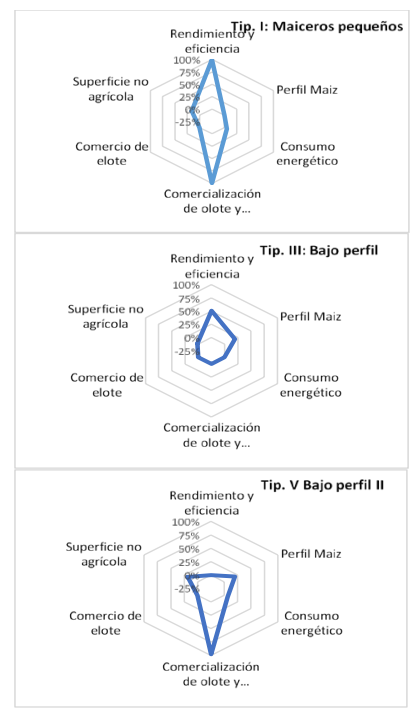

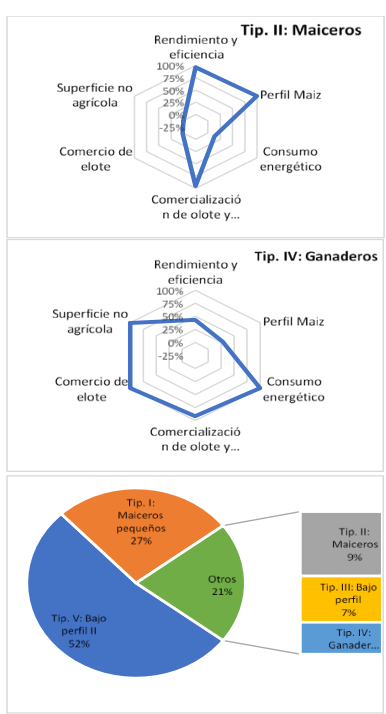

Figura 3. Caracterización de los tipos de productores definidos con base en las puntuaciones factoriales de las componentes.

Figure 3. Characterization of the defined producer's types based on the factorial scores of the components. 
Rev. Fac. Agron. (LUZ). 2021, 38: 176-198. Enero-Marzo.

Martínez-Aguilar et al.

ISSN 2477-9407

El tipo V ("Productores maízrastrojo" o bajo perfil II), es mayoritario, constituido por el $52 \%$ de los productores. Este grupo está limitado en el componente "Perfil maíz" y complementan su estrategia de ingresos con la comercialización del rastrojo. Muestran niveles de eficiencia inferior al resto de los grupos debido que la exportación de rastrojo del agroecosistema reduce los procesos de reciclaje de nutrientes asociados a la agricultura de conservación. Esto es consistente con sus suelos poco productivos y sometidos a procesos de degradación descritos por López et al. (2018) y López et al. (2019).

Los cinco tipos de productores evidencian una eficiencia energética superior a 10 MJ (energía producida/ energía consumida), lo que coincide con Pimentel (1980) quien encontró que la eficiencia energética promedio del cultivo de maíz es de 11,84 MJ producidos por cada MJ invertido. Es decir, en el área ocupada por estos municipios existen condiciones propicias para el cultivo del maíz sobre la base de insumos industriales, pero la integración de prácticas agroecológicas, también ha demostrado efectividad (López et al., 2019).

No obstante, entre los grupos de productores existen ciertas prácticas de producción, así como flujos financieros que los diferencian. Algunos de ellos, venden la producción en elote (mazorca tierna) con mejor precio de venta, a diferencia de quienes lo comercializan como grano. Por ello, el estudio energético y su flujo, resulta muy importante, sobre todo cuando
The five types of producers show an energy efficiency greater than $10 \mathrm{MJ}$ (energy produced / energy consumed), which coincides with Pimentel (1980) who found that the average energy efficiency of the corn crop is 11.84 MJ produced for each MJ invested. That is, in the area occupied by these municipalities, there are favorable conditions for the cultivation of corn based on industrial inputs, but the integration of agroecological practices has also shown effectiveness (López et al., 2019).

However, there are certain production practices among producer groups, as well as financial flows that differentiate them. Some of them sell their production in corn (tender corn) with a better sale price, unlike those who market it as grain. Therefore, the study of energy and its flow is very important, especially when it is necessary to know the efficiency of the agroecosystem (Mandal et al., 2002; Funes et al., 2011; Purroy-Vázquez et al., 2019).

\section{Energy efficiency}

The analysis of variance determined that the groups identified are different in terms of energy flows (Figure 4). Group I presents an energy efficiency of $17.37 \mathrm{MJ}$, followed by group II, with 16.13 MJ. Both groups have the most energy efficient producers, as a result of the adequate use of inputs by corn and the moment of its application, which makes efficient the transformation of the energy consumed versus the energy produced. The lowest values of energy efficiency are found in group V with $10.18 \mathrm{MJ}$ and group IV with $9.87 \mathrm{MJ}$. This is 
Rev. Fac. Agron. (LUZ). 2021, 38: 176-198. Enero-Marzo.

\section{Martínez-Aguilar et al.}

ISSN 2477-9407

se requiere conocer la eficiencia del due to the low use of industrial inputs agroecosistema (Mandal et al., 2002; Funes et al., 2011; Purroy-Vázquez et al., 2019). in the agroecosystem and because the soils are not very productive, that is, either degraded or in poor conditions

\section{Cuadro 4. Caracterización de las tipologías a partir de las variables originales*, asociadas a componentes.}

Table 4. Characterization of the typologies based on the original variables*, associated to the components.

\begin{tabular}{|c|c|c|c|c|c|c|c|c|}
\hline \multirow{2}{*}{ Comp. } & \multicolumn{2}{|l|}{ Tipología } & \multirow{2}{*}{$\begin{array}{l}\text { Tip. I } \\
80\end{array}$} & \multirow{2}{*}{$\begin{array}{c}\text { Tip. II } \\
28 \\
\end{array}$} & \multirow{2}{*}{$\begin{array}{c}\text { Tip. III } \\
20\end{array}$} & \multirow{2}{*}{$\begin{array}{c}\text { Tip. IV } \\
14 \\
\end{array}$} & \multirow{2}{*}{$\begin{array}{c}\text { Tip. V } \\
158 \\
\end{array}$} & \multirow[t]{2}{*}{$\mathrm{Sig}$} \\
\hline & Variables & $\mathrm{N}$ & & & & & & \\
\hline \multirow{6}{*}{ 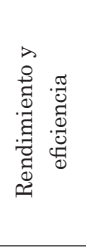 } & \multirow{2}{*}{$\begin{array}{c}\text { Eficiencia } \\
\text { energética }\end{array}$} & $\mathrm{X}$ & $17,29^{\mathrm{a}}$ & $1610^{\mathrm{a}}$ & $13,72^{\mathrm{b}}$ & $9,73^{\mathrm{c}}$ & $10,14^{\mathrm{c}}$ & \multirow{2}{*}{$* * *$} \\
\hline & & $\mathrm{DE}$ & 3,56 & 4,80 & 4,63 & 5,72 & 2,89 & \\
\hline & \multirow{2}{*}{$\begin{array}{l}\text { Rendimiento } \\
\left(\mathrm{kg}^{\mathrm{kg}} \mathrm{h}^{-1}\right)\end{array}$} & $\mathrm{x}$ & $4368,75^{\mathrm{a}}$ & $4928,57^{\mathrm{a}}$ & $3700,00^{\mathrm{b}}$ & $3678,57^{\mathrm{b}}$ & $276582^{\mathrm{c}}$ & \multirow{2}{*}{$* * *$} \\
\hline & & $\mathrm{DE}$ & 577,77 & 716,40 & 864,51 & 774,77 & 762,73 & \\
\hline & \multirow{2}{*}{$\begin{array}{c}\text { Energía producida } \\
\text { (Mcal) }\end{array}$} & $\mathrm{x}$ & $15975^{\mathrm{b}}$ & $18022^{\mathrm{a}}$ & $13529^{c}$ & $13451^{\mathrm{c}}$ & $10113^{\mathrm{d}}$ & \multirow{2}{*}{$* * *$} \\
\hline & & $\mathrm{DE}$ & 2112 & 2619 & 3161 & 2833 & 2789 & \\
\hline \multirow{6}{*}{  } & \multirow{2}{*}{ Superficie agrícola } & $\mathrm{x}$ & $2,58^{\mathrm{c}}$ & $8,37^{\mathrm{a}}$ & $3,21^{\mathrm{c}}$ & $6,64^{\mathrm{b}}$ & $4,19^{\mathrm{bc}}$ & \multirow{2}{*}{$* * *$} \\
\hline & & $\mathrm{DE}$ & 1,03 & 3,78 & 1,38 & 5,58 & 2,62 & \\
\hline & \multirow{2}{*}{ Superficie maíz } & $\mathrm{X}$ & $1,94^{\mathrm{d}}$ & $7,38^{\mathrm{a}}$ & $2,88^{\mathrm{c}}$ & $5,57^{\mathrm{b}}$ & $3,18^{\mathrm{c}}$ & \multirow{2}{*}{$* * *$} \\
\hline & & $\mathrm{DE}$ & 0,81 & 3,37 & 1,17 & 5,26 & 1,96 & \\
\hline & \multirow{2}{*}{ Ingresos totales } & $\mathrm{X}$ & $27993^{\mathrm{d}}$ & $130237^{\mathrm{a}}$ & $38712^{\mathrm{d}}$ & $53689^{\mathrm{b}}$ & $30339^{\mathrm{cd}}$ & \multirow{2}{*}{$* * *$} \\
\hline & & $\mathrm{DE}$ & 16148 & 51771 & 22616 & 39418 & 25438 & \\
\hline \multirow{4}{*}{ 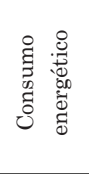 } & \multirow{2}{*}{ Energía directa } & $\mathrm{X}$ & $947,95^{c}$ & $1303,45^{\mathrm{b}}$ & $1036,91^{\mathrm{bc}}$ & $3156,89^{\mathrm{a}}$ & $1027,70^{\mathrm{bc}}$ & \multirow{2}{*}{$* * *$} \\
\hline & & $\mathrm{DE}$ & 157,10 & 868,76 & 238,18 & 4313,31 & 261,59 & \\
\hline & \multirow{2}{*}{$\begin{array}{l}\text { Intensidad } \\
\text { energética }\end{array}$} & $\mathrm{X}$ & $0,22^{c}$ & $0,28^{\mathrm{c}}$ & $0,32^{\mathrm{c}}$ & $0,89^{\mathrm{a}}$ & $0,40^{\mathrm{b}}$ & \multirow{2}{*}{$* * *$} \\
\hline & & $\mathrm{DE}$ & 0,04 & 0,23 & 0,18 & 1,21 & 0,17 & \\
\hline \multirow{4}{*}{ 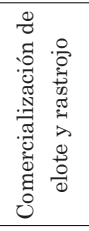 } & \multirow{2}{*}{$\begin{array}{l}\text { Comercialización } \\
\text { (Maíz en elote) }\end{array}$} & $\mathrm{X}$ & $4,00^{\mathrm{a}}$ & $3,96^{\mathrm{a}}$ & $3,20^{\mathrm{b}}$ & $3,71^{\mathrm{ab}}$ & $4,00^{\mathrm{a}}$ & \multirow[t]{2}{*}{$* * *$} \\
\hline & & $\mathrm{DE}$ & 0,00 & 0,19 & 1,06 & 0,61 & 0,00 & \\
\hline & Comercialización & $\mathrm{x}$ & $4,00^{\mathrm{a}}$ & $4,00^{\mathrm{a}}$ & $2,40^{\mathrm{b}}$ & $3,79^{\mathrm{ab}}$ & $3,94^{\mathrm{a}}$ & $* * *$ \\
\hline & (Maíz Rastrojo) & $\mathrm{DE}$ & 0,00 & 0,00 & 1,10 & 0,58 & 0,23 & 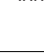 \\
\hline ث艹 & Ingresos Elote & $\mathrm{x}$ & 0,00 & 0,00 & $500,00^{\mathrm{b}}$ & $11803,57^{\mathrm{a}}$ & 0,00 & $* * *$ \\
\hline$\approx$ & & $\mathrm{DE}$ & 0,00 & 0,00 & 2236,07 & 13871,26 & 0,00 & \\
\hline ?ִ & Costo total & $\mathrm{X}$ & $9430^{\mathrm{b}}$ & $10615^{\mathrm{b}}$ & $10099^{\mathrm{b}}$ & $18624^{\mathrm{a}}$ & $9624^{\mathrm{b}}$ & \\
\hline ठี & $\begin{array}{c}\text { producción de } \\
\text { maíz }\end{array}$ & $\mathrm{DE}$ & 1622 & 2276 & 2221 & 5567 & 2392 & $* * *$ \\
\hline & Superficie & $\mathrm{X}$ & $0,93^{\mathrm{c}}$ & $2,11^{\mathrm{b}}$ & 0,00 & $25,50^{\mathrm{a}}$ & $3,45^{\mathrm{b}}$ & $* * *$ \\
\hline 苞 & ganadera (ha) & $\mathrm{DE}$ & 3,06 & 6,53 & 0,00 & 47,75 & 9,38 & \\
\hline 苛 & Superficie forestal & $\mathrm{X}$ & $1,03^{c}$ & $2,79^{b}$ & $0,86^{\mathrm{c}}$ & $15,57^{\mathrm{a}}$ & $2,69^{\mathrm{b}}$ & $* * *$ \\
\hline & (ha) & $\mathrm{DE}$ & 1,87 & 3,76 & 1,49 & 54,83 & 6,74 & \\
\hline
\end{tabular}


Rev. Fac. Agron. (LUZ). 2021, 38: 176-198. Enero-Marzo.

Martínez-Aguilar et al.

ISSN 2477-9407

Letras diferentes por filas, indican diferencias significativas $(p<0,05)$ al aplicar la prueba de Duncan. X: Promedio, DE: Desviación Estándar.

Different letters per row indicate significant differences $(\mathrm{p}<0,05)$ when applying Duncan's test. X: Average SD: Standard Deviation.

\section{Eficiencia energética}

El análisis de varianza determinó que los grupos identificados son diferentes en cuanto a los flujos de energía (Figura 4). El grupo I presenta una eficiencia energética de 17,37 MJ, seguido del grupo II, con 16,13 MJ. Ambos grupos tienen a los productores energéticamente más eficientes, como resultado del aprovechamiento adecuado de los insumos por parte del maíz y del momento de su aplicación, lo que hace eficiente la transformación de la energía consumida versus la energía producida. Los valores más bajos de la eficiencia energética los encontramos en el grupo $\mathrm{V}$ con 10,18 MJ y el grupo IV con 9,87 MJ. Esto se debe al bajo uso de insumos industriales en el agroecosistema y por presentar suelos pocos productivos, es decir, ya sea degradados o en malas condiciones para la producción. En ese sentido, Purroy et al. (2016) indican que la eficiencia energética de los agroecosistemas resulta ser una herramienta metodológica para la caracterización de productores.

En el análisis por municipio, no existió diferencia estadística significativa para la eficiencia energética del agroecosistema, ya que los valores fluctuaron entre 13,18 MJ y 14,17 MJ (Figura 4). Estos valores indican que el agroecosistema maíz, for production. In this sense, Purroy et al. (2016) indicate that the energy efficiency of agroecosystems turns out to be a methodological tool for the characterization of producers.

In the analysis by municipality, there was no statistically significant difference for the energy efficiency of the agroecosystem, since the values fluctuated between 13.18 MJ and 14.17 MJ (Figure 4). These values indicate that the maize agroecosystem, at the municipal level, is efficient in transforming energy, so it can be stated coincidentally with Purroy et al. (2019) that the agroecosystem presents viable productive and economic indicators.

In this sense, regarding grain production, the least efficient group of producers was II with 2.8 t.ha $^{-1}$, while the rest produced between 3.8 and 4.0 t.ha ${ }^{-1}$. However, these yields exceed that reported for Chiapas (1.9 t.ha-1) and 3.24 t.ha $^{-1}$ for the Frailesca region, where the four municipalities studied belong (SIAP, 2018), in addition, 70 $\%$ of the producers are classified as subsistence, and have a plot of less than 2.1 ha (ASICH, 2007).

\section{The forms of production}

Thetypology of producers associated with the forms of management of the corn agroecosystem by municipality, allowed to visualize the integration of the technology used in production with respect to the geographical area (Figure 5). The multiple correspondence analysis showed significant statistical associations between these variables. The forms of management are associated in the following way: the agroecological 
Rev. Fac. Agron. (LUZ). 2021, 38: 176-198. Enero-Marzo.

Martínez-Aguilar et al.

ISSN 2477-9407

al nivel municipal, es eficiente en la transformación de la energía, por lo que se puede afirmar coincidentemente con Purroy et al. (2019) que el agroecosistema presenta indicadores productivos y económicos viables. system with group II, the mixed system with group IV and the conventional system with groups I, III and V. However, in the municipal analysis, it is observed that Villaflores, Villa Corzo and El Parral are associated

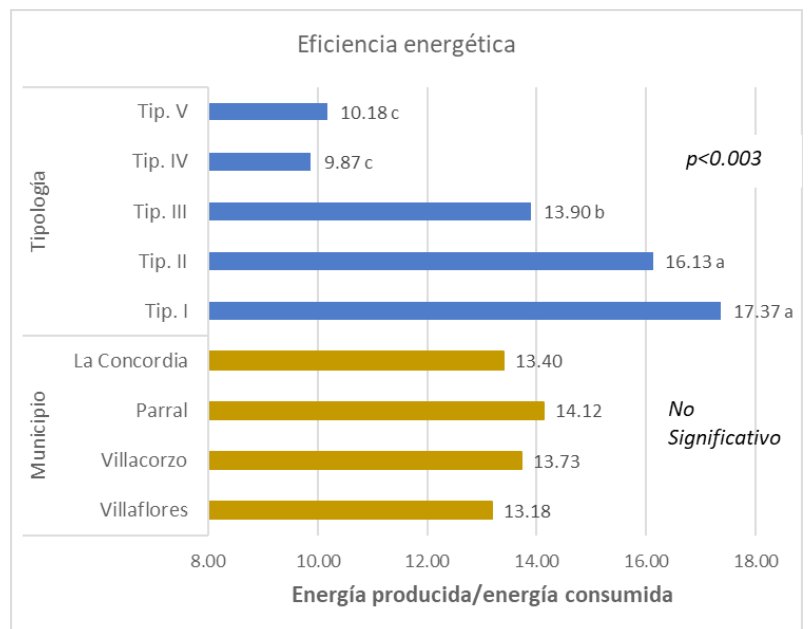

Figura 4. Indicadores de eficiencia energética de productores de maíz en cuatro municipios de la Frailesca, Chiapas.

Figure 4. Energy efficiency indicators for corn producers, in four municipalities of La Frailesca, Chiapas.

En ese sentido, respecto a la producción en grano, el grupo de productores menos eficiente fue el II con 2,8 t.ha ${ }^{-1}$, mientras que el resto produjo entre 3,8 y 4,0 t.ha $^{-1}$. Sin embargo, estos rendimientos superan a lo reportado para Chiapas (1,9 t.ha $\left.{ }^{-1}\right)$ y de 3,24 t.h h $^{-1}$ para la región Frailesca, a la que pertenecen los cuatro municipios estudiados (SIAP, 2018), donde además el $70 \%$ de los productores son clasificados como de subsistencia, y poseen una parcela menor de 2,1 ha (ASICH, 2007). with the conventional management system, La Concordia with the mixed system and again Villaflores with the agroecological management system.

The conventional management system is characterized by the high use of agrochemicals to produce corn, it also has flat land for mechanization; Therefore, in the long term, it presents problems of degradation of the soil resource, which causes a loss in the productive capacity of the agroecosystem. According to Gliessman et al. (2007), the conventional production model 
Rev. Fac. Agron. (LUZ). 2021, 38: 176-198. Enero-Marzo.

Martínez-Aguilar et al.

ISSN 2477-9407

\section{Las formas de producción}

La tipología de productores asociada a las formas de manejo del agroecosistema maíz por municipio, permitió visualizar la integración de la tecnología empleada en la producción con respecto a la zona geográfica (Figura 5). El análisis de correspondencia múltiple mostró asociaciones estadísticas significativas entre estas variables. Las formas de manejo se asocian de la siguiente manera: el sistema agroecológico con el grupo II, el sistema mixto al grupo IV y el sistema convencional a los grupos I, III y V. Sin embargo, en el análisis municipal, se observa que Villaflores, Villa Corzo y El Parral se asocian al sistema de manejo convencional, La Concordia al sistema mixto y nuevamente Villaflores al sistema de manejo agroecológico.

El sistema de manejo convencional, se caracteriza por el uso elevado de agroquímicos para producir maíz, además cuenta con terrenos planos para la mecanización; por ello, a largo plazo presenta problemas de degradación del recurso suelo, lo que provoca pérdida en la capacidad productiva del agroecosistema. Según Gliessman et al. (2007) el modelo convencional de producción ha ocasionado problemas al suelo debido a la presión permanente, degradación constante y no utilización de prácticas para contrarrestar los efectos de largo plazo.

El sistema de manejo mixto presenta niveles altos de flujos económicos y consumo energético, porque la producción se vende en elote y no en grano como los otros grupos. has caused problems to the soil due to permanent pressure, constant degradation and the non-use of practices to counteract the long-term effects.

The mixed management system presents high levels of economic flows and energy consumption, because the production is sold in corn and not the grain like the other groups. In addition, they carry out two or more corn sowings during the year, they are irrigated and do not depend on the rains. In this sense, Pimentel (2005) indicates that the increase or decrease in corn production is mainly due to the high economic costs of production, dependence on non-renewable energy resources, the degradation of the natural resources of the agroecosystem and the low stability crop yield.

The agroecological management system is associated with the municipality of Villaflores and is characterized by good energy efficiency and marketing projection. The cultivated areas are greater than 4 ha per producer. These conditions favor the development of the corn crop and increase its yield. In the short and medium term, the forms of mixed and agroecological management are considered less productive; However, in the long term, they become sustainable with the implementation of agroecological practices (Espinosa et al., 2011). Along these lines, AguilarJiménez et al. (2011) indicate that in the long term, the corn agroecosystem under agroecological management presents greater sustainability compared to conventional forms of management. 
Rev. Fac. Agron. (LUZ). 2021, 38: 176-198. Enero-Marzo.

Martínez-Aguilar et al.

Además de que realizan dos o más siembras de maíz durante el año, cuentan con riego y no dependen de las lluvias. En este sentido, Pimentel (2005) indica que el incremento o disminución de la producción de maíz se debe principalmente a los altos costos económicos de producción, la dependencia de recursos energéticos no renovables, la degradación de los recursos naturales del agroecosistema y la poca estabilidad del rendimiento de los cultivos.

\section{Conclusions}

In the municipalities of Villaflores, Villa Corzo, El Parral and La Concordia, five types of corn producers were identified, which are differentiated on the basis of six components that explained $83 \%$ of the total variance, among which the following stand out: Yield and Efficiency; the Corn Profile in the production system in general and the Energy Consumption.

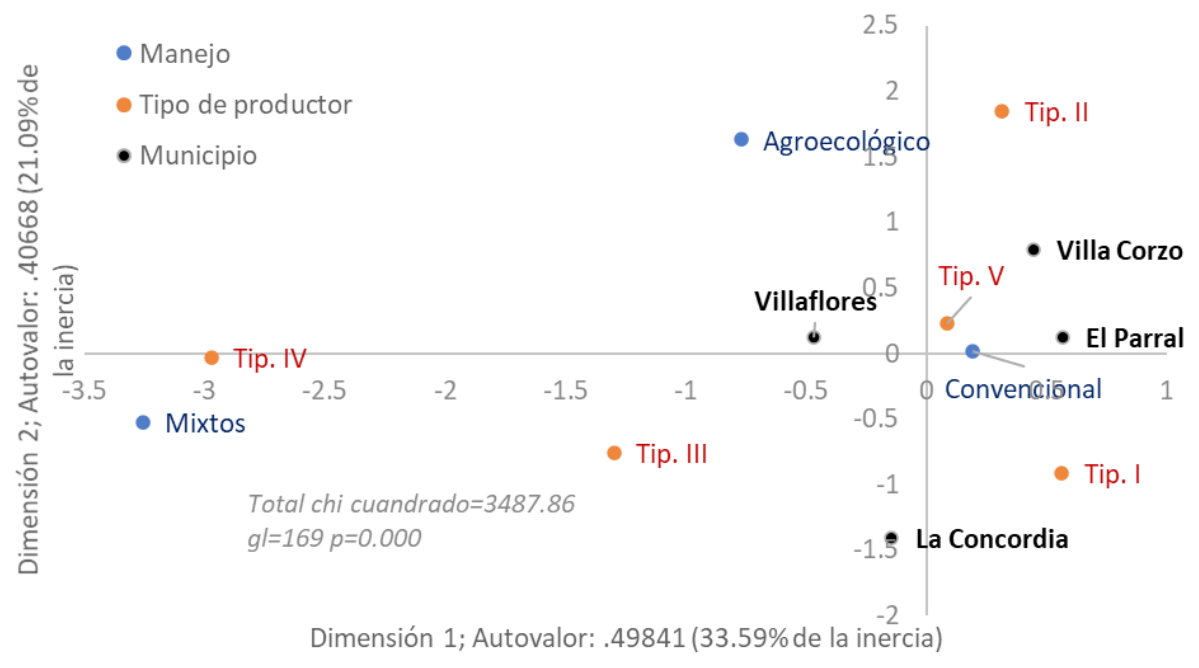

Figura 5. Asociaciones entre la tipología definida y las formas de producción en cuatro municipios de la Frailesca, Chiapas.

Figure 5. Associations between the defined typology and the forms of production in four municipalities of La Frailesca, Chiapas.

El sistema de manejo agroecológico se asocia al municipio de Villaflores y se caracteriza por una buena eficiencia energética y proyección en la comercialización. Las áreas cultivadas son superiores a 4 ha por productor. Estas condiciones
The types of producers found are characterized by having small areas for sowing corn, but have high yields and direct marketing with the buyer. The grain yields in all identified typologies are above the average for the state of Chiapas and are efficient 
favorecen el desarrollo del cultivo de maíz e incrementan su rendimiento. En el corto y mediano plazo, las formas de manejo mixto y agroecológico son consideradas menos productivas; sin embargo, en el largo plazo, se hacen sustentables con la implementación de prácticas agroecológicas (Espinosa et al., 2011). En ese tenor, AguilarJiménez et al. (2011) indican que, en el largo plazo, el agroecosistema maíz bajo un manejo agroecológico presenta mayor sustentabilidad respecto a las formas de manejo convencionales.

\section{Conclusiones}

En los municipios de Villaflores, Villa Corzo, El Parral y La Concordia se identificaron cinco tipos de productores de maíz los cuales se diferencian sobre la base de seis componentes que explicaron el $83 \%$ de la varianza total, entre las que se destacan: el Rendimiento y Eficiencia; el Perfil Maíz en el sistema productivo en general y el Consumo Energético.

Las tipologías de productores encontradas se caracterizan por tener superficies pequeñas para la siembra de maíz, pero presentan altos rendimientos y una comercialización directa con el comprador. Los rendimientos de grano en todas tipologías identificadas están por encima de la media del estado de Chiapas y son eficientes desde el punto de vista energético, de acuerdo a la energía directa empleada en el agroecosistema.

Dos de los grupos identificados mostraron un perfil de productores puros de maíz, pero con escalas from the energy point of view, according to the direct energy used in the agroecosystem.

Two of the groups identified showed a profile of pure maize producers, but with different scales. These were named as: "Small Producers" and "Major Producers". The remaining three groups received the following labels: "Mixed livestock-corn producers", "Subsistence producers" and "Corn-stubble producers".

The five groups of producers are associated with conventional, agroecological and mixed management forms characterized in the region. The management of conventional agriculture predominates in $86 \%$ of the systems studied, associated with groups I, III and V.

\section{Acknowledgments}

This article is part of the first author's doctoral thesis project and is titled "The sustainability of the corn agroecosystem (Zea mays L.) in the Frailesca region, Chiapas. Mexico". We are grateful to the Autonomous University of Chiapas, for the support and the opportunity to carry out the doctoral studies, to the Program for Teacher Professional Development (PRODEP) for the scholarship granted and to all the producers who provided valuable information for the development of this research.

End of English Version 
Rev. Fac. Agron. (LUZ). 2021, 38: 176-198. Enero-Marzo.

Martínez-Aguilar et al.

diferentes. Estos se nombraron como: "Productores pequeños" y "Productores mayores". Los restantes tres grupos recibieron las siguientes etiquetas: "Productores mixtos ganaderíamaíz", "Productores de subsistencia" y "Productores maíz-rastrojo".

Los cinco grupos de productores están asociados a formas de manejo convencional, agroecológica y mixtas caracterizadas en la región. Predomina el manejo de agricultura convencional en el $86 \%$ de los sistemas estudiados, asociado a los grupos I, III y V.

\section{Agradecimientos}

Este artículo forma parte del proyecto de tesis doctoral del primer autor y es titulada "La sustentabilidad del agroecosistema maíz (Zea mays L.) en la región Frailesca, Chiapas. México". Se agradece a la Universidad Autónoma de Chiapas, por el apoyo y la oportunidad de realizar los estudios doctorales, al Programa para el Desarrollo Profesional Docente (PRODEP) por la beca otorgada y a todos los productores que proporcionaron información valiosa para el desarrollo de la presente investigación.

\section{Literatura citada}

Aguilar-Jiménez, C. E., B. A. Tolón y B. X Lastra. 2011. Evaluación integrada de la sostenibilidad ambiental, económica y social del cultivo de maíz en Chiapas, México. Revista de la Facultad de Ciencias Agropecuarias UNCUYO. Tomo 43, Año 1. pp. 155-174.

Agencia de Servicios Informativos de Chiapas (ASICH). 2007. Producción de maíz en Chiapas. Agencia de servicios Informativos de Chiapas.
Altieri, M. A. 2002. Agroecología: principios y estrategias para diseñar sistemas agrarios sustentables. En: SARANDON, SJ Agroecología: el camino hacia una agricultura sustentable. Buenos Aires-La Plata, Pp: 49-56. Disponible en: http://agroeco.org/wp - content/ uploads/2010/10/cap2-Altieri.pdf

Chambers, R. 1993. Challenging the professions. Frontiers for rural development. IT Publications, London. Pp. 35-70.

Delgado-Ruiz, F., F. Guevara-Hernández y R. Acosta-Roca. 2018. Criterios campesinos para la selección de maíz (Zea mays L.) en Villaflores y Villa Corzo, Chiapas, México. Ciencia UAT. 13(1):123-134. DOI: https://doi. org/10.29059/cienciauat.v13i1.985.

Delgado, R. F. 2017. Evaluación energética y económica del sistema de producción de maíz (Zea mays L.) bajo prácticas convencionales y de conservación en la región Frailesca. Tesis de Maestría. Facultad Ciencias Agronómicas de la Universidad Autónoma de Chiapas. Villaflores, Chiapas. México. 83 p. Disponible en: https://www.academia. edu/44081433/Evaluaci\%C3\%B3n_ e n e r g \% C $3 \%$ A 9 t i c a y $_{-}$ econ\%C3\%B3mica_del_sistema_ de_producci\% C $3 \% \bar{B} 3 n_{-} \mathrm{de}_{-}$ ma\%C3\%ADz_Zea_mays_L_bajo_ pr\%C3\%A1cticas_convencionales_y_ de_conservaci\%C3\%B3n_en_la_ regi\%C3\%B3n_Frailesca_Chiapas. Fecha de consulta: Noviembre, 2019.

Escobar, G. y J.A. Berdegué. 1990. Conceptos y metodología para la tipificación de sistemas de finca. En: Escobar, G. and Berdegué, J.A. (Eds.). Tipificación de Sistemas de Producción Agrícola. RIMISP, Santiago. Pp. 11-63. Disponible en: https://idl-bnc-idrc.dspacedirect.org/ bitstream/andle/10625/3969/49675. pdf? sequence $=1$. Fecha de Consulta: Noviembre, 2018.

Espinosa, J.A., L.A. Ríos, M. Zapata. 2011. Los diseños agroecológicos: una herramienta para la planeación agrícola sostenible. Medellín: Universidad de Antioquia. Medellín. 71 p. Disponible en: https:// biblioteca.ihatuey.cu/link/libros/ 


\section{Rev. Fac. Agron. (LUZ). 2021, 38: 176-198. Enero-Marzo.}

\section{Martínez-Aguilar et al.}

sistemas_agroforestales/disenos_ agroecologicos.pdf. Fecha de consulta: Diciembre, 2019.

Funes, M. F, J. Suarez, D. Blanco, F. Reyes, L. Cepero, J.L. Rivero, E. Rodríguez, V. Savran, Y. del Valle, M. Cala, M. Vigil, , J.A. Sotolongo, , S. Boillat, , J.E. Sánchez, 2011. Evaluación inicial de sistemas integrados para la producción de alimentos y energía en Cuba. Pastos y Forrajes. 34(4):445462.

Funes, M. F. 2009. Agricultura con futuro, la alternativa agroecológica para Cuba. Estación Experimental Indio Hatuey. ISBN 9789597138020. Universidad de Matanzas. 176 p. Disponible en: https://isbn.cloud/en/9789597138020/ agricultura-con-futuro/. Fecha de consulta: Enero, 2019.

Gliessman, S.R., M.F.J. Rosado, Z.C. Guadarrama, J. Jedlicka, A. Cohn, V.E. Mendez, R. Cohen, L. Trujillo, C. Bacon y R. Jaffe. 2007. Agroecología: promoviendo una transición hacia la sostenibilidad. Ecosistemas. 16 (1). Pp. 13-23.

Guevara, H. F., R. F. Delgado, L. M. Arias, L. L. Rodríguez, P. R. Ortiz, R. J. A. Delgado, V. J. A. Venegas y R. R. Pinto. 2018. Comparative energyeconomic analysis of the maize agroecosystem under conventional and conservation practices in the Frailesca region, Chiapas. Mexico. Rev. Fac. Agron. (LUZ). 35:343-364. Caracas, Venezuela.

Guevara-Hernández, F. 2007. “Y después qué?: Action-research and ethnography on governance, actors and development in Southern Mexico". Technology and Agrarian Development Group. Department of Social Sciences. Wageningen University and Research Centre. Wageningen, The Netherlands. $223 \mathrm{p}$. Disponible en: https://www.academia. edu/39061800/Y_despu\%C3\%A9s_ qu\%C3\%A9_Action_research_and_ ethnography_on_governance_actors_ and_development_in_Southern_ Mexico. Fecha de consulta: Enero 2019.

Hagmann, J. 1999. Learning together for change: facilitating innovation in natural resource management through learning process approaches in rural livelihoods in Zimbabwe. MargrafVerlag. Weirkershein, Germany. 310 p. Disponible en: https://www.researchgate.net/ publication/307632899_Learning_ together_for_Participatory Extension_A_Guide_to_an Approach_Developed_in_Zimba we//57cdced508ae582e06923c97/ download. Fecha de consulta: Enero, 2019.

Hellin, J., O. Erenstein, T. Beuchelt, C., Camacho and D. Flores, 2013. Maize stover use and sustainable crop production in mixed crop-livestock systems in Mexico. Field Crops Res. http://dx.doi. org/10.1016/j.fcr.2013.05.014.

IDAE (Instituto para la diversificación y ahorro de la energía, ahorro y eficiencia energética con agricultura de conservación). 2009. Ahorro y eficiencia energética en la agricultura. No. 12. Gobierno de España. Ministerio de Industria, Turismo y Comercio. 56 p. Disponible en: https://www.idae. es/uploads/documentos/documentos_ 10995_Agr12_Agric_conservacion_ A2009_1ef06e4a.pdf. Fecha de consulta: Diciembre, 2018.

INEGI (Instituto Nacional de Estadística, Geografía e Informática). 2018. Dirección General de Estadísticas Económicas. México. IX Censo Agrícola, Ganadero y Forestal. Panorama agropecuario en Chiapas Censo Agropecuario 2014-2018. Fecha de consulta: Enero, 2019.

López, B. W., R. Reynoso, B. Villar, R. Camas y J. O. García. 2018. Diagnóstico de la compactación en suelos cultivados con maíz en la región Frailesca, Chiapas. Revista Mexicana de Ciencias Agrícolas. Volumen 9 (1). Texcoco, Estado de México. Pp. 897-910.

López, B. W., R. Reynoso, B. Villar, R. Camas y J. O. García. 2019. Caracterización físico-química de suelos cultivados con maíz en Villaflores, Chiapas. Revista Mexicana de Ciencias Agrícolas. Volumen 10 (4): 897-910. DOI: https:// doi.org/10.29312/remexca.v10i4.1764

Mandal, K. G., K. P. Saha, K.M. Ghost, K. M. Hati, K. K. Bandyopadhyay. 2002. 
Bioenergy and economic analysis of soybean-based crop production systems in central India. Biomas and Energy 23:337-345.

Masera, O., M.Astier. 1995. Energíay sistema alimentario en México: Aportaciones de la agricultura alternativa, en Agroecología y Desarrollo Agrícola en México, Universidad Autónoma Metropolitana, Xochimilco, México D. F.

Méndez-Cortés, V., J. S. Mora-Flores, J. A. García-Salazar, O. HernándezMendo, R. García-Mata, y R. C. García-Sánchez. 2019. Tipología de productores de ganado bovino en la zona norte de Veracruz. Tropical and Subtropical Agroecosystems 22 (2019): 305-314.

Ocaña, J. M. 2015. Estudio socioeconómico y ambiental del uso y manejo del rastrojo en los sistemas maízganadería en la región Frailesca, Chiapas. Tesis de maestría. Universidad Autónoma de Chiapas. Tuxtla Gutiérrez, Chiapas. 110 p. Disponible en: https://www. academia.edu/44081414/Estudio_ cioecon\%C3\%B3mico_y_ambiental_ del_uso_y_manejo_del_rastrojo_ en_los_sistemas_ma\%C3\%ADz_ g a n a d e r \% C $3 \% \mathrm{AD} a_{-}$en_la regi\%C3\%B3n_Frailesca_Chiapas. Fecha de consulta: Enero, 2019.

Perales, H. R., B. F. Benz, , S. B. Brush. 2005. Maize diversity and ethnolinguistic diversity in Chiapas, Mexico. Proc. Natl. Acad. Sci. U.S.A. 102, 949-954.

Pimentel D. 2005. Environmental and economic costs of the application of pesticides primarly in the United States. Env. Dev. Sust. 7: 229-252.

Pimentel, D. 1980. Handbook of Energy Utilization in Agriculture. CRC Press, Boca Ratón, FL. SP. Pp. 51-90.

Purroy-Vázquez, R.; E. Ortega-Vargas, Q. Hernández-Santiago, O. Del ÁngelPiña, J. Meza-Hernández, B. ReyesSantiago, F. Nicolás-Vicente. 2019. Maize small-scale agroecosystems in the high Huasteca region of Veracruz: Economic-energetic efficiency and poverty. Agric. Soc. Desarro (On line). 16 (1). Pp.105-121.
Purroy V., F. Gallardo, P. Díaz, E. Ortega, S. López y G. Torres. 2016. Energeticeconomic flow as a tool to typify agroecosystems in the center of the state of Veracruz, Mexico. Ecosistemas y recursos agropecuarios 3(7):91-101.

Rodríguez, L. y F. Guevara. 2009. Innovación y Desarrollo Rural: Reflexiones y experiencias desde el contexto cubano. 1a edición (Versión Digital). ACSUR-Las Segovias/IIA Jorge Dimitrov. Madrid, España. 174 p. https://www.academia.edu/44081348/ Innovaci\%C3\%B3n_y_Desarrollo_ Rural_Experiencias_y_reflexiones_desde_el_contexto_Cubaño. Fecha de consulta: Diciembre, 2018.

SAGARPA (Secretaria de Agricultura, Ganadería, Desarrollo Rural, Pesca y Alimentación). 2017. Maíz grano blanco y Amarillo Mexicano. Planeación Agrícola Nacional 20172030. Ciudad de México. 36 p. https:// www.gob.mx/cms/uploads/attachment/ file/256429/B_sico-Ma_z_Grano_ Blanco_y_Amarillo.pdf. Fecha de consulta: Enero, 2019.

Sánchez, M. P., F. I. Ocampo, I. F. Parra, E. J. Sánchez, R. A. María y M. A. Argumedo. 2014. Evaluación de la sustentabilidad del agroecosistema maíz en la región de Huamantla, Tlaxcala, México. Agroecología 9: 111-122.

Scheaffer, R., W. Mendenhall y L. Otto. 2004. Elementos de muestreos, grupo Editorial Iberoámericana, México. p. 15. https://issuu.com/hectorm. delossantos-posadas/docs/elementos_ de_muestreo_-_schaffer_et. Fecha de consulta: febrero 2018.

SIAP (Servicio de Información Agroalimentaria y Pesquera). 2018. Atlas agroalimentario (SAGARPA). Ciudad de México. Disponible en: http://www.siap.gob.mx/ Fecha de consulta: Enero, 2019.

StatSoft, Inc. 2007. STATISTICA (Data analysis software system), versión 8.0. Boston, USA. Disponible en: https:// statistica.software.informer.com/8.0/.

Toledo, M. V. 2015. ¿De qué hablamos cuando hablamos de sustentabilidad? Una propuesta ecológico política. Interdisciplina 3 (7): 35-55. 